\title{
Actinomycosis of the breast and lungs
}

\author{
Herbert L. Fred, MD ${ }^{\text {a† }}$, Gabriel M. Aisenberg, $M D^{a}$ (D), and Hendrik A. van Dijk ${ }^{b}$

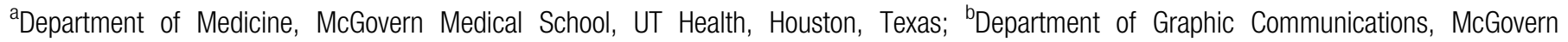 \\ Medical School, UT Health, Houston, Texas
}

\section{ABSTRACT}

Actinomycosis is a chronic, progressive, and often relapsing granulomatous infection that characteristically crosses tissue planes and forms abscesses and sinus tracts. We report a unique case of a woman with actinomycosis presenting with a breast abscess, a sinus tract spontaneously exiting the sternum, and miliary lung lesions.

KEYWORDS Actinomycosis; breast abscess; miliary lung lesion; sinus tract; sulfur granules

\section{CLINICAL HIGHLIGHTS}

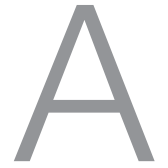

50-year-old woman presented with a 1-year history of dyspnea on exertion; a 2-week history of a painful, swollen right breast; and a 10-day history of constant pressure and aching discomfort in the lower part of her sternum. On examination, she had a tender, warm right breast and several draining 6sinuses in and near the sternum (Figure 1a). A chest radiograph showed diffuse miliary lesions bilaterally with increased markings in the right lower lung field (Figure 1b). Contrast material injected into a sinus opening in the lower sternum demonstrated irregular tracts and cavities up to $5 \mathrm{~cm}$ in diameter in the soft tissues of the right breast and chest wall (Figure 1c). There was no connection between these abnormalities and the pleural space or lung.

The clinical findings suggested three diagnostic possibilities: tuberculosis, actinomycosis, and inflammatory carcinoma of the breast. Incision of the right breast uncovered pockets of pus, but stains and cultures of the pus for acidfast, fungal, and bacterial organisms were negative. Open lung biopsy, however, showed microabscesses containing sulfur granules. Cultures of this material again were sterile, and stains showed no pathogens. Nevertheless, the combination of draining sinuses with sulfur granules pointed strongly to actinomycosis as the primary disease. Accordingly, the patient received high doses of penicillin intravenously for 6 weeks. By the end of that therapy, the breast abscess had healed, the sinus openings had closed, and the lung lesions had all but disappeared.

\section{DISCUSSION}

Actinomycosis is a chronic, progressive, and often relapsing granulomatous infection that characteristically crosses tissue planes and forms abscesses and sinus tracts. ${ }^{1-3}$ It frequently simulates other infections and malignancy, clinically and radiologically. ${ }^{1,4}$ Various organisms from the genus Actinomyces cause the disease; they are Gram-positive, rod-shaped, anaerobic or microaerophilic bacilli that are difficult to grow and are recovered in less than half of the cases. ${ }^{5,6}$ In the appropriate clinical setting, however, the finding of sulfur granules virtually guarantees the diagnosis of actinomycosis. ${ }^{3,4,7}$ Long-term antibiotic therapyespecially with penicillin, coupled at times with surgical intervention-is generally recommended and can be curative. $^{1-3,5}$

Actinomycosis causing breast abscess is rare in $\operatorname{men}^{8-12}$ as well as in women. ${ }^{4,12-23}$ As a cause of miliary lung lesions ${ }^{24-28}$ or of spontaneous sinus tracts exiting the sternum, ${ }^{29,30}$ it is even rarer. Yet, all three of these manifestations were evident simultaneously in our patient. From a literature search, this case appears to be unique.

\section{BOTTOM LINE}

If the patient has a breast abscess, a sinus tract spontaneously exiting the sternum, miliary lung lesions, or 

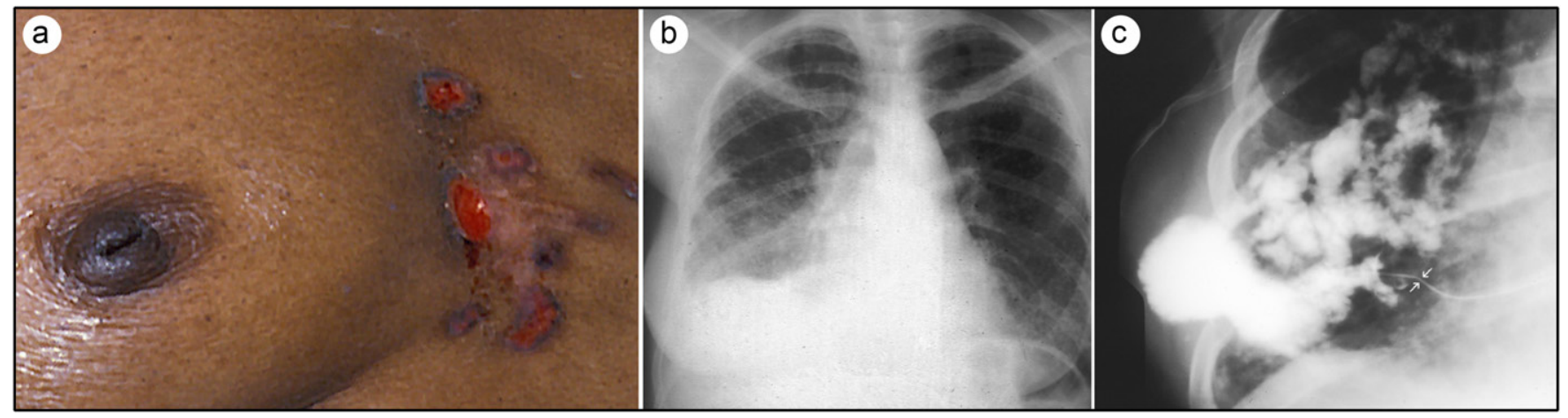

Figure 1. (a) Clinical photograph showing the right breast and several sinus openings in and near the lower sternum. (b) Chest radiograph depicting miliary densities throughout both lungs and increased markings in the right lower lung field. (c) Sinogram demonstrating contrast material in a sinus tract (arrows) and multiple cavities in the soft tissues of the right breast and chest wall.

any combination thereof, actinomycosis—-despite its relative rarity—could be the culprit.

\section{ORCID}

Gabriel M. Aisenberg iD http://orcid.org/0000-0003-0826-1427

1. Wong VK, Turmezei TD, Weston VC. Actinomycosis. BMJ. 2011; 343:d6099.

2. Smego RA, Foglia G. Actinomycosis. Clin Infect Dis. 1998;26(6): $1255-1261$.

3. Bennhoff DF. Actinomycosis: diagnostic and therapeutic considerations and a review of 32 cases. Laryngoscope. 1984;94(9): $1198-1217$.

4. Thambi R, Devi L, Sheeja S, Poothiode U. Primary breast actinomyces simulating malignancy: a case diagnosed by fine-needle aspiration cytology. J Cytol. 2012;29(3):197-199. doi:10.4103/0970-9371.101173.

5. Brook I. Actinomycosis: diagnosis and management. South Med J. 2008;101(10):1019-1023. doi:10.1097/SMJ.0b013e3181864c1f.

6. Lee JH, Jeon SC, Jang HJ, Kim H, Kim YH, Chung WS. Primary sternal osteomyelitis caused by Actinomyces israelii. Korean J Thorac Cardiovasc Surg. 2015;48(1):86-89. doi:10.5090/kjtcs.2015.48.1.86.

7. Varkey B. Sulfur granules. JAMA. 1982;248(22):3025.

8. Gueron M. Actinomyces meyerii breast abscess. Am J Med. 1988;84(2): 369. doi:10.1016/0002-9343(88)90447-0.

9. Dershaw DD. Actinomycosis of the chest wall. Ultrasound findings in empyema necessitans. Chest. 1984;86(5):779-780.

10. Mahendiran SA, Leibman AJ, Kommehl AS. Male breast abscess secondary to actinomycosis: a case report. J Clin Diagn Res. 2016;10(4):5-7.

11. Nielsen HL. First report of Actinomyces europaeus bacteremia result from a breast abscess in a 53-year-old man. New Microbes New Infect. 2015;7:21-22. doi:10.1016/j.nmni.2015.05.001.

12. Attar KH, Waghorn D, Lyons M, Cunnick G. Rare species of actinomyces as causative pathogens in breast abscess. Breast J. 2007;13(5): 501-505. doi:10.1111/j.1524-4741.2007.00472.x.

13. Al-Niaimi F, Patel A, Blessing K, Fox R, Burden AD. Cutaneous actinomycosis presenting as chronic mastitis. Clin Exp Dermatol. 2010;35(2):149-151. doi:10.1111/j.1365-2230.2009.03159.x.
14. White SE, Woolley SD. Actinomyces europaeus isolated from a breast abscess in a penicillin-allergic patient. Case Rep Infect Dis. 2018;2018: 6708614. doi:10.1155/2018/6708614.

15. Allen JN. Actinomyces meyerii breast abscess. Am J Med. 1987;83(1): 186-187.

16. Leenstra BS, Schaap CCM, Bessems M, Renders NHM, Bosscha K. Primary actinomycosis in the breast caused by Actinomyces neuii. A report of 2 cases. ID Cases. 2017;8:70-72. doi:10.1016/j.idcr.2017.03.014.

17. Rich BS, Angeles C, Barie PS. Actinomyces odontolyticus breast abscess. Surg Infect (Larchmt). 2013;14(3):331-332. doi:10.1089/sur.2012.090.

18. Gogas J, Sechas M, Diamantis S, Sbokos C. Actinomycosis of the breast. Int Surg. 1972;57(8):664-665.

19. Salmasi A, Asgari M, Khodadadi N, Rezaee A. Primary actinomycosis of the breast presenting as a breast mass. Breast Care (Basel). 2010; 5(2):105-107. doi:10.1159/000301599.

20. Gosavi AV, Anvikar AR, Sulhyan KR, Manek DD. Primary actinomycosis of breast-a diagnosis on cytology. Diagn Cytopathol. 2016; 44(8):693-695. doi:10.1002/dc.23499.

21. Mohammed KN. Actinomycosis of the accessory breast treated with cotrimoxazole. Med J Malaysia. 1993;48(2):229-231.

22. Bing AU, Loh SF, Morris T, Hughes H, Dixon JM, Helgason KO. Actinomyces species isolated from breast infections. J Clin Microbiol. 2015;53(10):3247-3255. doi:10.1128/JCM.01030-15.

23. Silva WA, Pinheiro AM, Jahns B, Bögli-Stuber K, Droz S, Zimmerli S. Breast abscess due to Actinomyces europaeus. Infection. 2011;39(3): 255-258. doi:10.1007/s15010-011-0119-3.

24. Harris AM, Priestley JB. Actinomycosis. Report of a case with miliary chest lesions. J Lab Clin Med. 1944;29(8):815-819.

25. Schinz HR, Blangey R. Generalized actinomycosis. Röntgenpraxis 1934;6:169-172.

26. Fisher MS. Miliary actinomycosis. J Can Assoc Radiol. 1980;31(2): 149-150.

27. Parker JS, deBoisblanc BP. Case report: Actinomycosis: multinodular pulmonary involvement. Am J Med Sci. 1994;307(6):418-419.

28. Xu Y, Shi J. Disseminated actinomycosis. N Engl J Med. 2018; 379(11):1071. doi:10.1056/NEJMicm1802090.

29. McQuarrie DG, Hall WH. Actinomycosis of the lung and chest wall. Surgery. 1968;64(5):905-911.

30. Fred HL, van Dijk HA. Disseminated actinomycosis. In Images of Memorable Cases: 50 Years at the Bedside. Houston, TX: Rice University Press; 2007:159-160. 